\title{
Petrological Characteristics of the Peddavura Schist Belt and Adjacent Rocks in Eastern Dharwar Craton in Parts of Nalgonda District, Telangana State
}

\author{
Lakshmi Pagidoju ${ }^{1}$, Naresh Bandari ${ }^{2}$, Narsing Rao Alwal ${ }^{1}$ \\ ${ }^{1}$ Department of Geology, Osmania University, Hyderabad, India \\ ${ }^{2}$ CSIR-National Geophysical Research Institute, Hyderabad, India \\ Email: *lakshmi.pagidoju@gmail.com
}

How to cite this paper: Pagidoju, L., Bandari, N. and Alwal, N.R. (2018) Petrological Characteristics of the Peddavura Schist Belt and Adjacent Rocks in Eastern Dharwar Craton in Parts of Nalgonda District, Telangana State. Open Journal of Geology, 8 , 124-134.

https://doi.org/10.4236/ojg.2018.82008

Received: January 2, 2018

Accepted: February 8, 2018

Published: February 11, 2018

Copyright $\odot 2018$ by authors and Scientific Research Publishing Inc. This work is licensed under the Creative Commons Attribution International License (CC BY 4.0).

http://creativecommons.org/licenses/by/4.0/

\begin{abstract}
The Peddavura greenstone Linear Belt, NW-SE trending, is formed in the Eastern part of the Dharwar Craton of south India, extended over $62.5 \mathrm{sq} \cdot \mathrm{km}$ in Nalgonda and Guntur districts region. The entire belt is illustrated as Peninsular Gneiss. The Belt Study has attracted geologists for conducting further research to evaluate the crust forming process at the time of early volcanic eruption of Earth's history. The South Indian Dharwar Craton depicts and exposes the crustal segments where geological activities took place consistently during the Precambrian. The PSB (Peddavura Schist Belt) mostly consists of meta volcanic (meta basalts), amphibolites, granites, dolerites, basaltic andesites, pegmatite and Banded Magnetite Quartzite's (BMQ) rock types. The 20 represented rock samples made for thin section studies. Based on the Petrological studies minerals are showing uralitization, saussuritization in the granite with mylonite structures, perthite and dolerite are showing heavy metal such as rutile and other opaque minerals (Magnetite, hematite, and typical pyrite crystal) are present in different represented rock samples. The minerals are showing different alteration zones along with microstructures. Using the Petrological studies the minerals and rock types are identified in the study region.
\end{abstract}

\section{Keywords}

Transmitted Light Microscopy, Reflected Light Microscopy, Peddavura Schist Belt, Eastern Dharwar Craton

\section{Introduction}

The Dharwar Craton perhaps separated by the Closepet Batholith Granite is di- 
vided into Eastern (EDC) and Western (WDC) Dharwar Craton, on the basis of inferred Metamorphic, Lithological differences and Magmatic Genetic incidents. The WDC forms a Boundary Fault between them along the Eastern location of the Chitradurga schist belt. The EDC is characterized by voluminous late Archaean Granitoids of 2.51 - $2.75 \mathrm{Ga}$, with minor gneisses TTG-Tonalite-TrondhjemiteGranodiorite and Migmatites, dominated by thin Volcanic Lithologies schist belt along Dharwar age. It seems that Chronologic and the Genetic bonds between plate tectonics and mantle thermal processes were Archaean Earth complex stages, while the Schist Belt Craton is metamorphosed of Greenschist to Amphibolites Facies regional metamorphism [1]. There is an extraordinary metal concentrated Mineral deposit forming Magmatic, and Magmatic-Hydrothermal Geodynamic environmental processes typically of high thermal and mechanical energy close to plate boundaries. With specific environmental provisions, they form specific mineral deposit to occupy Geodynamic Niches. Such temporal distributed mineral deposits reflect the formation and preservation processes, in the Palaeoproterozoic Archaean linked to the continental crust and connected to Sub Continental Lithospheric Mantle-SCLM, decoupled later by Phanerozoic, and Neoproterozoic, making it denser. Due to environmental changes, and natural impact on the preserved mineral deposit, they formed an integral part of the tectonic process, of Geodynamic Settings, incorporating into any holistic Tectonic Terrain. Such restructured constructions offer targeting tool to explore the conceptual requirements to discover and locate new mineral deposits in the provinces under study cover [2]. Study of Archean greenstone belts is important to understand processes responsible for crustal growth and mantle differentiation as they contain earliest records of the earth's history [3]. The greenstone belts commonly consist of komatiites, tholeiites, felsic volcanic rocks and sedimentary rocks like phyllites, banded iron formation (BIF) and carbonates. The unique feature about the greenstone belts (e.g. Abitibi, Kolar, and Kambala) is that they host precious metallic mineral deposits (e.g. Au, PGE, Ni, Cu) and hence generated considerable interest among geologists to know the relationship between early crust formation and genesis of the ore deposits [4]. The greenstone belts were subjected to different degree of metamorphism from lower greenschist to upper amphibolite facies. The relation between the rocks of the greenstone belt, surrounding granitoids and metamorphism are important to understand the crustal evolution during the Archean period.

Cratons present in the Indian peninsular are Dharwar Craton in the south, Bastar Craton in the central, Singhbum Craton in the east and Aravalli-Bundelkhand Craton in the west [5]. The Dharwar Craton is the largest craton in Indian peninsular having typical Archean greenstone-granite terranes with most of the major rock units ranging in age from Meso- to Neo-archean [6].

\section{Geology of the Dharwar Craton}

The Dharwar Craton has been relatively well studied; tectonic setting for the formation of granitoid rocks and greenstone belts of the craton is a debated issue 
[7] [8] proposed that EDC was formed by the accretion of an island arc against foreland WDC in a convergent tectonic setting during Neoarchean. The EDC greenstone belts are considered as an intra-arc basin, whereas the WDC as back-arc basins. Whereas [9] favored a plume growth model where in the role of mantle plumes are related to the widespread Neoarchean plutonism, reworking and diapiric structures. Combinations of these two end-member models are suggested by a number of workers like [9] that included initial subduction followed by closure of oceanic domain and arc collision tectonic settings. Ram Mohan, et al. (2013) has suggested subduction processes for the generation of felsic magmatism based on the geochemical and isotopic studies [10]. Krogstad et al. (1989), Anand et al. (2010 \& 2014) are suggested that the greenstone belts and granitoid rocks of EDC were formed predominantly by horizontal compressional forces [11] [12] [13]. The Dharwar craton was stabilized at 2.5 Ga. During Paleoproterozoic widespread mafic dyke activity took place within the Dharwar Craton [14].

The previous studies are $\mathrm{U}-\mathrm{Pb}$ zircon ages and $\mathrm{Nd}$ isotope data for the felsic volcanic rocks from seven Neoarchean greenstone belts of the Eastern Dharwar craton (EDC) and from the Chitradurga greenstone belt in the Western Dharwar craton (WDC). The $2.70-2.65 \mathrm{Ga}$ felsic volcanic event is contemporaneous with 2.7 Ga mafic greenstone volcanism and emplacement of Tonalitic to Granodioritic crust, while $2.58-2.54 \mathrm{Ga}$ felsic volcanics are spatially and probably genetically in some cases linked to the major episode of Calc-Alkaline magmatic accretion in the EDC. The Chitradurga and Veligallu greenstone belts host felsic volcanics of the first generation, the latter showing inheritance at ca. $2.95 \mathrm{Ga}$. Four of the five greenstone belts hosting the second generation of felsic volcanic Chitradurga, Kolar, Kadiri, Hutti, show crustal inheritance at Ga. 2.6, 2.7, 2.9, 3.0, 3.1 and 3.3 Ga [15]. Hutti, Ramagiri, Kolar, Kushtagi, Penakacherla, and Gadwal greenstone belts of the EDC (Figure 1) have been studied for their geochemistry. Kolar greenstone belt consists of komatiites, tholeiites, and dacites. Whereas, the Hutti is madeup of tholeiitic basalts, dacites, and rhyolite with rare occurrence of ultramafic rocks [16] [17]. The field observations, $\mathrm{Rb}-\mathrm{Sr}$ and $\mathrm{Sm}-\mathrm{Nd}$ isotope studies, geochemical studies are indicating the rocks are classified as basalt, basaltic andesite, andesite, dacite, and rhyolite [17].

\section{Geology of the Study Area}

The Greenschist is formed into metamorphic rock formed at the lowest temperature of $350^{\circ} \mathrm{C}$, and a pressure of 4-kilo bars, producing regional metamorphism, with abundant green minerals like Muscovite and serpentine, besides chlorine, and Epidote. The other common minerals are the Orthoclase, Quartz, Amphiboles-Actinolite, and Carbonate minerals. The Peddavura schist belt is NW-SE treading, hook-shaped (Figure 2) extended to $25 \mathrm{~km}, 0.5$ to $2 \mathrm{~km}$ wide in the Nalgonda and Guntur Districts. It is $150 \mathrm{~km}$ South of Hyderabad near the Nagarjuna Sagar Dam, as it tapers down and vanishes towards the North of 


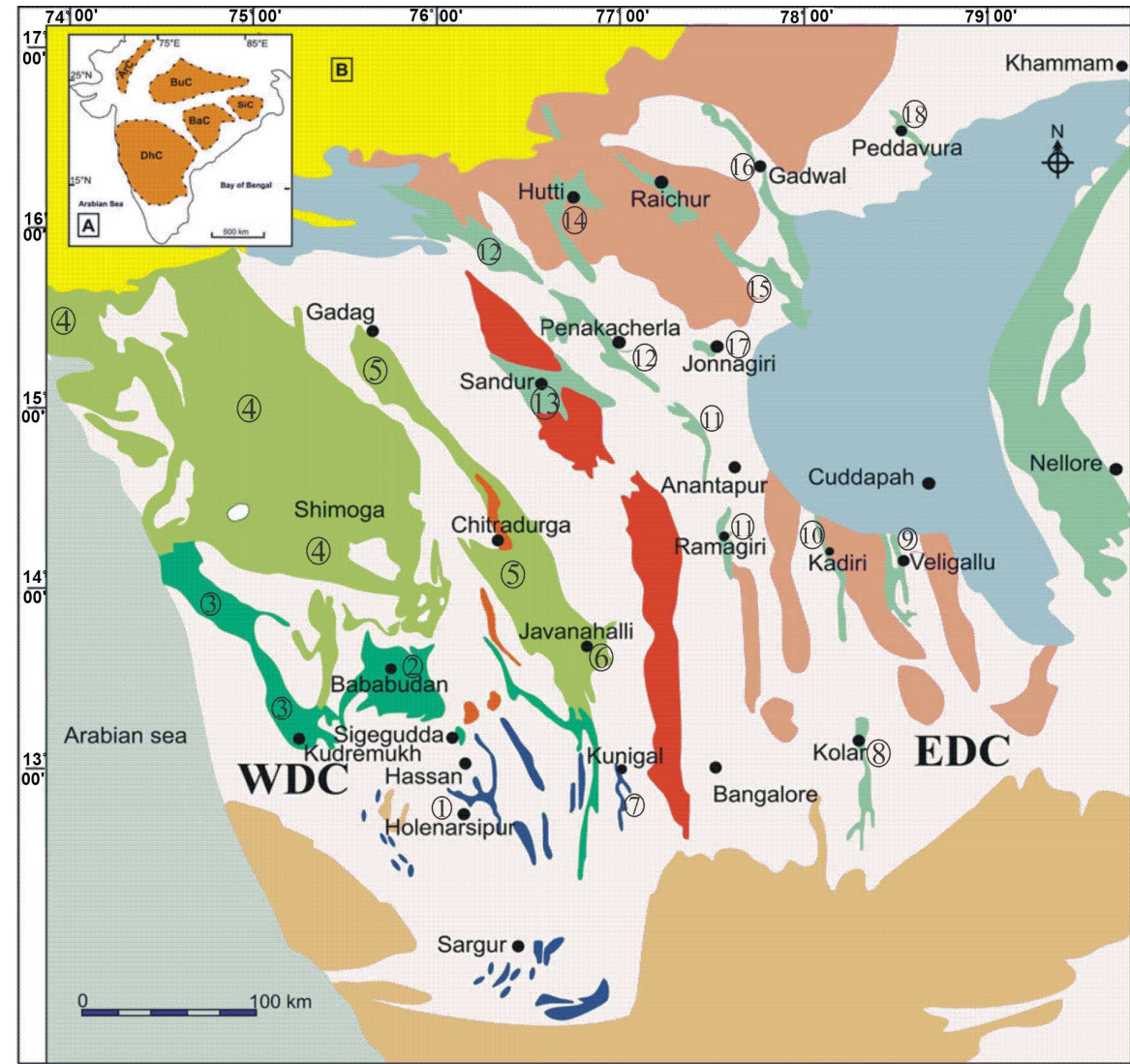

\begin{tabular}{|c|c|c|c|c|}
\hline \multicolumn{5}{|c|}{ Legend } \\
\hline & $2.61 \mathrm{Ga}$ high-K plutons & Deccan basalts & 1.Holenarsipur & 10.Kadiri \\
\hline & EDC greenstone belts & & 2.Bababudan & 11.Ramagiri \\
\hline & & & 3.Kudremukh & 12.Kushtagi \\
\hline & Chitradurga Group & Charnokites & $\begin{array}{l}\text { 4.Snimoga } \\
\text { 5.Chitradurqa }\end{array}$ & $\begin{array}{l}\text { 13.Sandur } \\
\text { 14. Hutti }\end{array}$ \\
\hline & Bababudhan Group & Clospet batholith & $\begin{array}{l}\text { 6.javana halli } \\
\text { 7.Kunigal }\end{array}$ & $\begin{array}{l}\text { 15.Raichur } \\
\text { 16.Gadwal }\end{array}$ \\
\hline & Sargur Group & EDC plutons & $\begin{array}{l}\text { 8.Kolar } \\
\text { 9 Veligallu }\end{array}$ & 17.Jonnagiri \\
\hline & TTG gneisses & & & \\
\hline
\end{tabular}

Figure 1. Geological map of Dharwar Craton [17].

Jugudem, in the NW gneisses. The southern part is exposed to Proterozoic Cuddapah of Sandstone and quartzite. The belt forms a spectacular bend at the South Eastern end of Tummurukota, to disappear under the small Cuddapah cover. The schist belt, Western arm is bound by treating NW-SE fault lineament [18].

The NW trending peddavura schist belt hosting metabasalts, granitoids and quartz reefs, dolerites, Banded magnetite quartzite. Along the peddavura schist belt coarse-grained hornblende-biotite bearing granite is exposed. Metabasalts (amphibolite) are highly metamorphosed intruded with later quartz veins (Figure 3(a)). The schist belt intruded by dolerite dykes alternatively (Figure 3(b)). The NW part of the schist belt represented by BMQ and structurally deformed. 


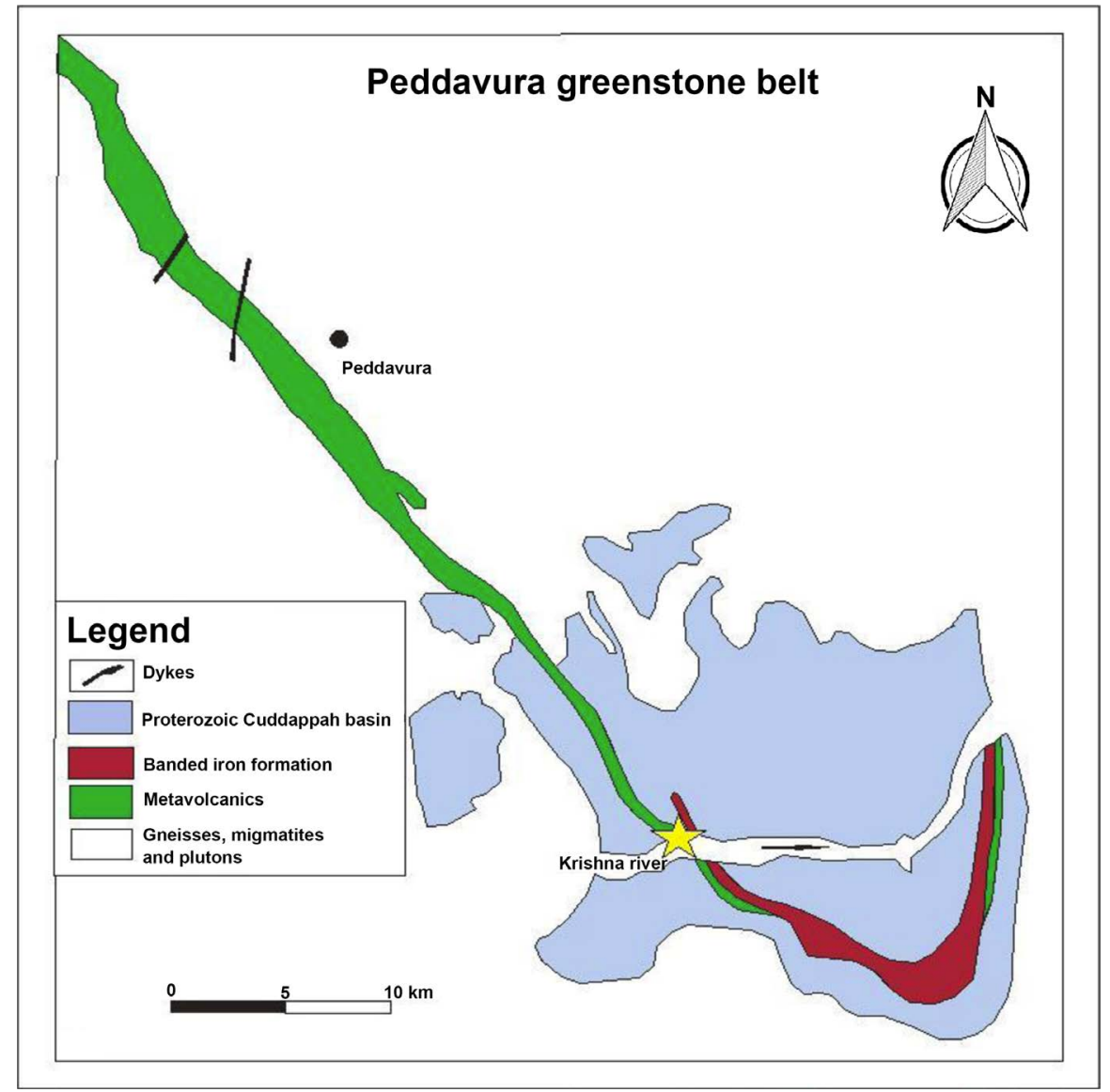

Figure 2. Geological map of the Peddavura greenstone belt [17].

The continuously fold structure developed in the NW part of the schist belt (Figure 3(c)). Due to the impact of weathering some of the locations in the schist belt have found as pelitic schist (Figure 3(d)).

\section{Analytical Methods}

Rock samples were collected as random sampling based on the different distribution of rock types from schist belt and adjacent rocks with the use of top sheet of the study area. About one kg sample was collected from each location. A total 15 rock samples of all samples were collected. The geographic coordinates of all sampling points were determined with the global positioning system, thin sections for petrological studies and laboratory studies. Out of these 6 samples were metabasalts, 5 samples were felsic rocks and 4 samples were dolerites, BMQ.

\section{Petrography}

\subsection{Transmitted Light Microscopy}

The plane of Dextral appearing in quartz bordered with Plagioclase, whose presence on the Sericite is known as Saussuritization. Here crystallized quartz surrounds the Plagioclase feldspar, called mylonite, which is formed by ductile 


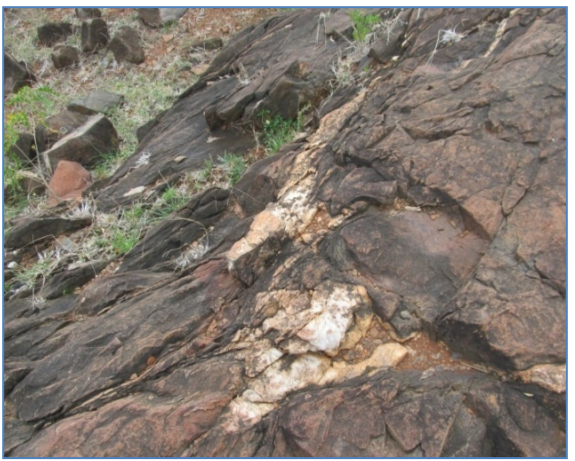

(a)

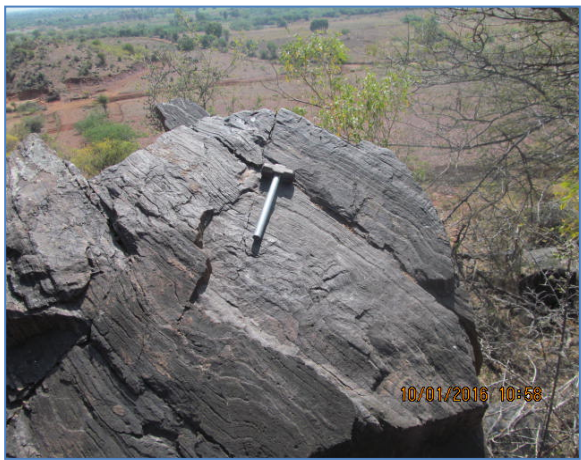

(c)

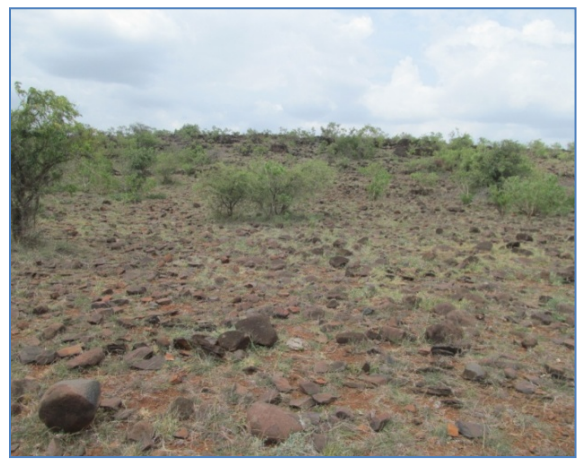

(b)

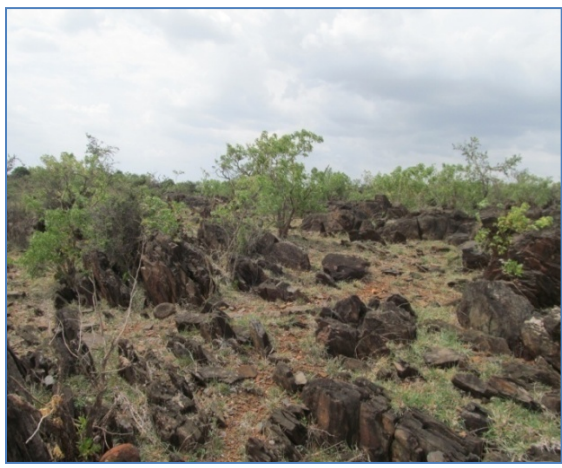

(d)

Figure 3. (a) Highly metamorphosed schist with quartz vein; (b) Alternate schist and dyke formations; (c) Banded Magnetite Quartzite; (d) Outcrop of the schist belt.

deformation. Later, the Biotites were altered to Chlorites. The presence of Microcline, K-feldspar is showing twinning (Figure 4(a)). The Saussuritization of Plagioclase, similar to the above figure, is altered into the Sericite, to form Hornblende (Figure 4(b)). Rutile formation is in altered Dolerite. Rutile is an economically important mineral. It is associated with mafic rocks such as dolerite. Here dolerite is in altered stage and minerals are plagioclase feldspar and biotite is alteration stage that is chlorite (Figure 4(c)). Foliation structure is showing chlorite schist (Figure 4(d)). Metabasalt is showing Uralitization and Actinolite is showing needle-like structure (Figure 4(e)). The Perthite texture is in sheared granite (Figure 4(f)). The banded iron ore minerals are associated with Precambrian banded iron formations are mainly found in three oxy-hydroxy phases as hematite, magnetite. The ore minerals and their textural features are in BHF, different types of iron ores along with quartzites. The iron ores are illustrating with magnetization (Figure $4(\mathrm{~g})$ ). Quartz grains are highly sheared stretched and altered alternate bands of iron ores are present. Basaltic andesite exhibits porphyritic texture in which amphibole as a phenocryst (Figure $4(\mathrm{~h})$ ) surrounded by plagioclase feldspars. The groundmass consists of plagioclase and quartz, few pyroxenes. Few porphyroblasts of amphiboles, plagioclase, and quartz are along the schistosity (Figure 4(i)) some pyroxenes, opaques are present. Prominent foliations are visible in these rocks. Mostly plagioclase is altered in this rock. 


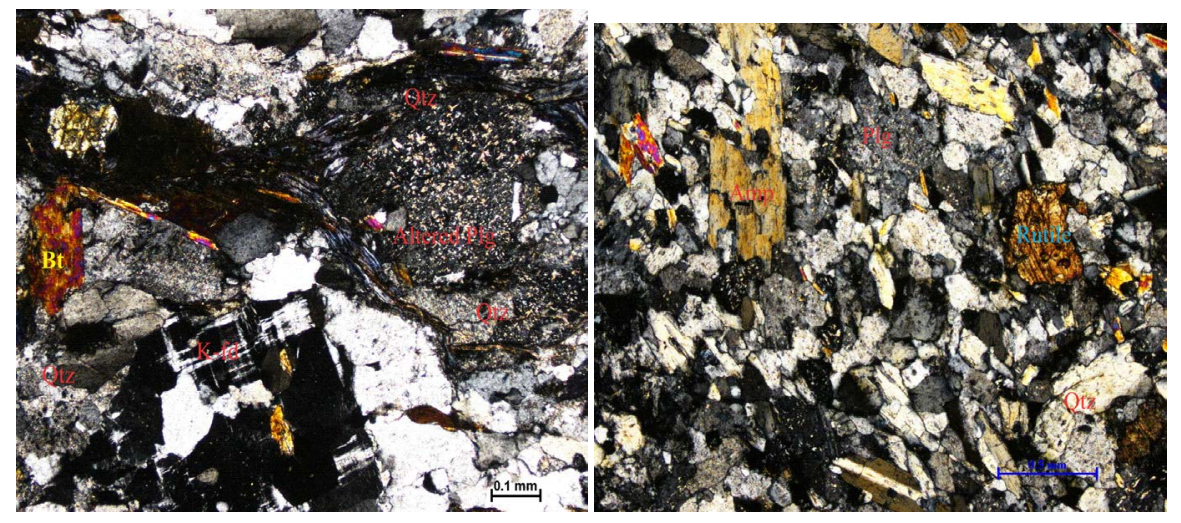

(a)

(b)

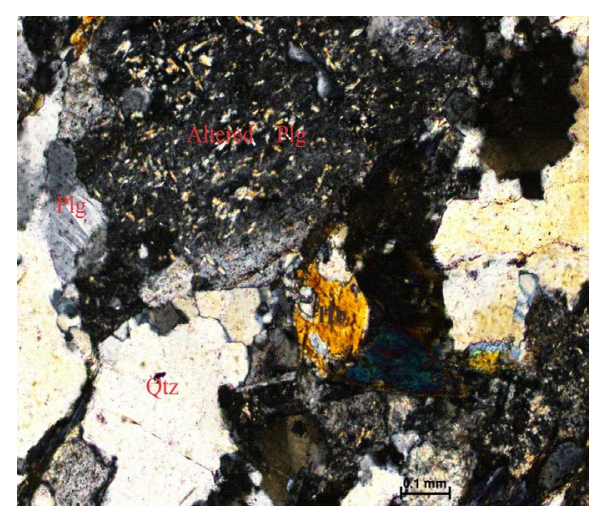

(c)

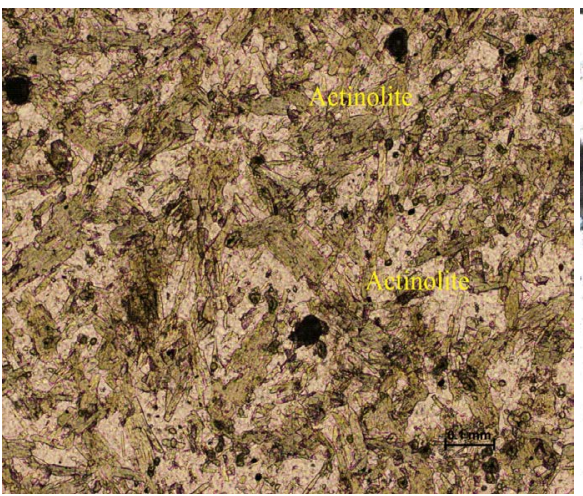

(e)

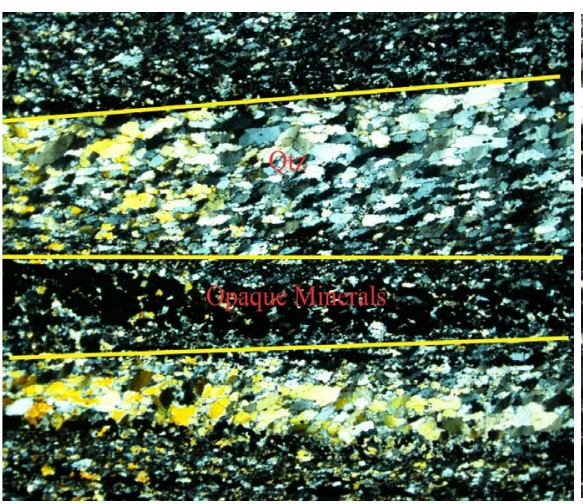

(g)

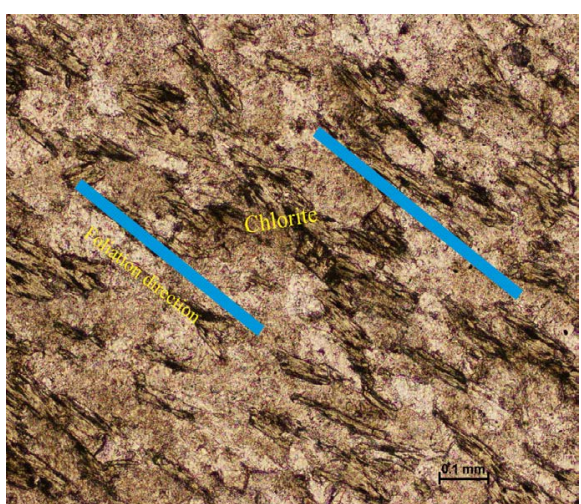

(d)

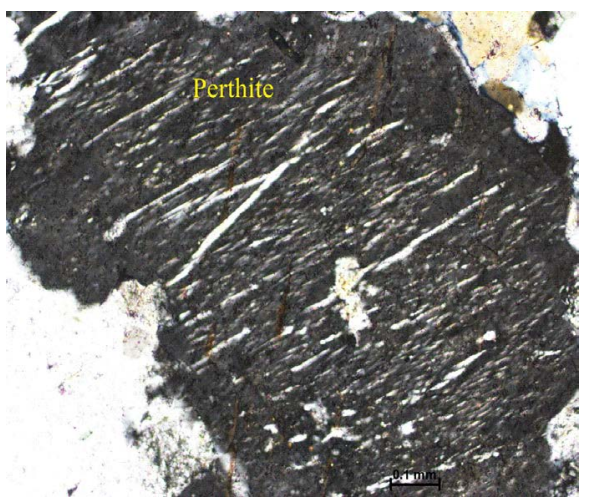

(f)

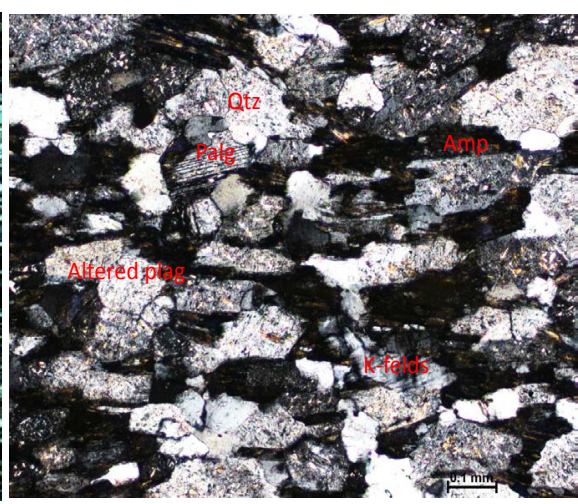

(h) 


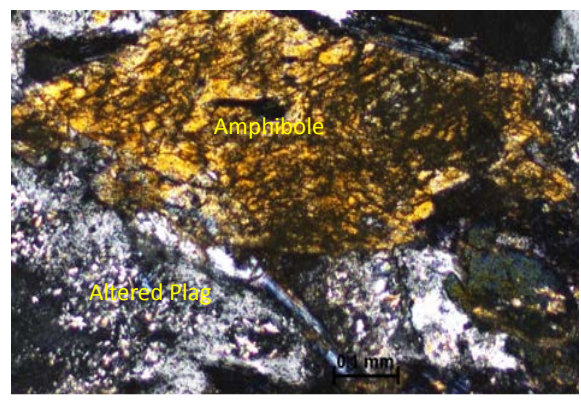

(i)

Figure 4. (a) Rounded plagioclase porphyroclast surrounded by granulated quartz grains and biotite, K-feldspar in sheared granite; (b) Recrystallised quartz, plagioclase laths, amphibole \& rutile are present in the granitoids; (c) Altered plagioclase and hornblende also present in sheared granite; (d) Foliation structure is represented by chlorite mineral and foliation direction is towards the south side in this section; (e) Metabasalt is associated with needle-like actinolite crystals; (f) Perthite is present in the sheared granite; (g) Banded Magnetite Quartzite clearly showing alternate bands of quartzite and opaque minerals; (h) Basaltic andesite showing plagioclase, qtz minerals in andesite; (i) Phenocryst of amphibole grain present in the basaltic altered in stage.

\subsection{Reflected Light Microscopy}

A special picture of the crystal of Pyrite sheared granite (Pyrite crystal $=\mathrm{Fes}_{2}$ ) (Figure 5(a)). Under Oil immersion, the hematite is replacing magnetite in Banded magnetite quartzite rock. The BMQ is associated with magnetite and hematite ore minerals and gray color portion is magnetite and yellow color portion is hematite (Figure 5(b)). Oil immersion microscope, hematite replaces magnetite in magnetite quartzite rock shows some fractured filling of the ore vein in BMQ (Banded Magnetite Quartzite), with iron ore minerals like hematite and magnetite. The gray portion is hematite, while hematite reflects with colloform texture. Hematite replaces magnetite and colloform texture all around, finely forming a kidney like mineral texture by ultra-fine-grained rhythmic precipitation once thought to denote deposition of colloids. The colloform textures give an evidence of colloidal deposition, rhythmically and asymmetrically crustified Veins (Figure 5(c)). The Chalcopyrite $\left(\mathrm{CuFeS}_{2}\right)$ in sheared granite intruded by felisic lava is associated with sulfide minerals, pyrite and chalcopyrite. Here felisic lava combines with disseminated chalcopyrite and pyrite grains. Such mineralization of sulfide minerals is structurally controlled. Greenstone belts of the Eastern Dharwar Craton, is full of Komatiite and association of volcanic Mg and Fe. Tholeiitic Basalt with deep water siliciclastic and banded iron formation (BIF) rocks are assemblage with Proterozoic sediments (Figure 5(d)).

\section{Conclusion}

The peddavura Schist Belt is linear trending NW-SE hook-shaped belt associated with different rock types such as metabasalts (chlorite schist), pegmatites, dolerite dykes with alternate schist formations, Banded Magnetite Quartzite (BMQ), granitoids intruded by felsic lava. In the peddavura schist belt, the mineralization 


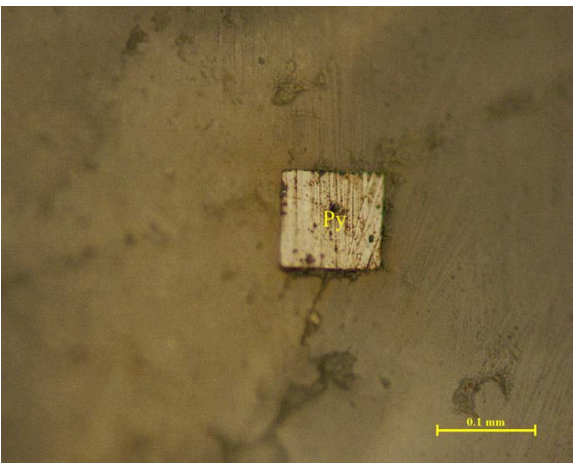

(a)

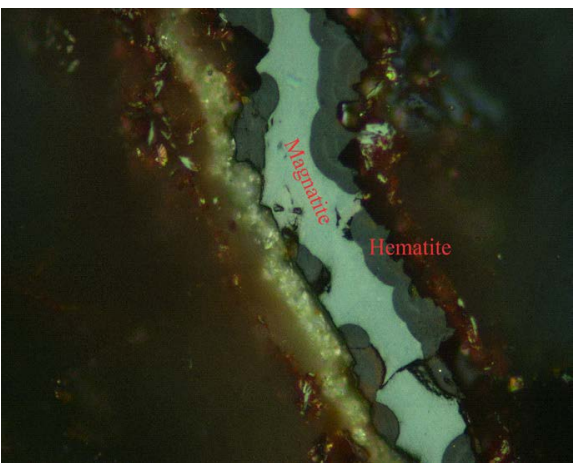

(c)

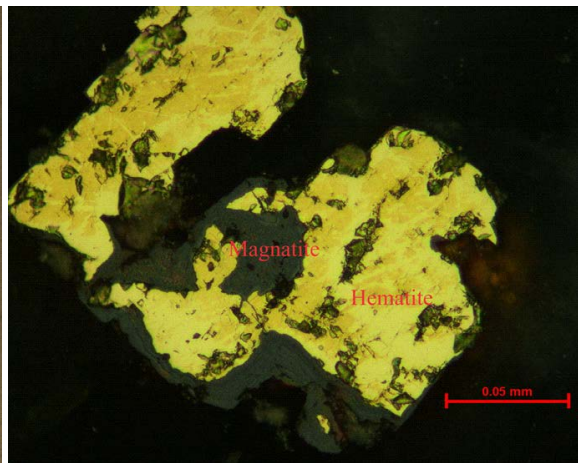

(b)

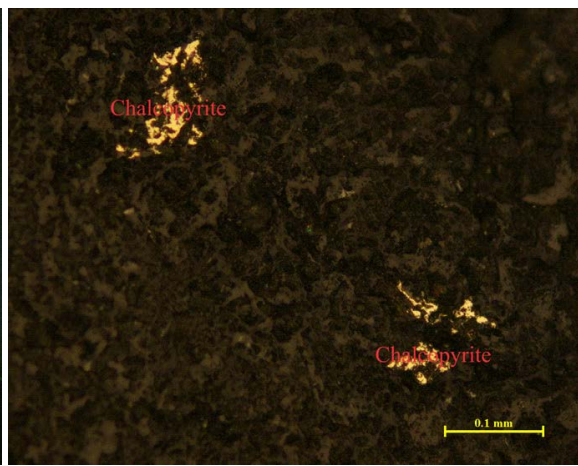

(d)

Figure 5. (a) A typical pyrite $\left(\mathrm{FeS}_{2}\right)$ in sheared granite with felsic magnetite lava rock sample; (b) Under Oil immersion, the hematite is replacing in Banded magnetite quartzite rock, gray color reflects magnetite and yellow color reflects hematite mineral; (c) Colloform texture: here rhythmically and asymmetrically magnetite and hematite are formed in fracture filling deposits; (d) Chalcopyrite $\left(\mathrm{CuFeS}_{2}\right)$ is present in which is intrude by felisic lava into the granite.

was mostly controlled by structures. Petrologically BMQ was alternating layers of quartz and magnetite, hematite iron ores. In the study area, hematite replaces the magnetite in colloform texture. This texture is appeared in rhythmically and asymmetrically formed in fractures. These mineral deposits are called fracture filling deposits. A typical pyrite crystal is present in granitoid intruded by felsic lava. Sheared granite represented saussuritization and uralitization due to alteration and recrystallized quartz, biotite altered to chlorite, plagioclase altered to sericite. The sulfide minerals like pyrite, chalcopyrite, magnetite, and hematite are associated with mafic rocks. The alternations were due to different grades of metamorphism and tectonic movements.

\section{Acknowledgements}

The author P. Lakshmi is thankful to her mentor Prof. A. Narsing Rao, Department of Geology Osmania University, Hyderabad for his constant encouragement and support in providing the necessary laboratory facilities and Filed work. Thanks to DST-Inspire for providing research fellowship to the first Author. We are also thankful to Dr. Santanu Bhatacharjee Director, Geological Survey of In- 
dia, Hyderabad, for his enormous support in the laboratory Microscopic analysis.

\section{References}

[1] Sundar Raju, P.V., et al. (2014) A Review of the Inferred Geodynamic Evolution of the Dharwar Craton, over the ca.3.5-2.5Ga Period, and Possible Implications for Global Tectonics. Canadian Journal of Earth Sciences, 51, 312-325. https://doi.org/10.1139/cjes-2013-0145

[2] Groves, D.I. and Bierlein, F.P. (2006) Geodynamic Settings of Mineral Deposit Systems. Journal of the Geological Society, 164, 19-30.

https://doi.org/10.1144/0016-76492006-065

[3] Rajamanickam, M. (2015) Geochemical and Rb-Sr \& Sm-Nd Isotopic Studies on Metavolcanic Rocks from Peddavura Greenstone Belt and Granitoid Rocks of the Dharwar Craton: Significance to Archean Crustal Evolution. Doctor's Thesis, Chemical \& Applied Sciences Pondicherry University, Puducherry, 1-3. http://dspace.pondiuni.edu.in/jspui/bitstream/1/2079/1/T5926.pdf

[4] Muller, A.G., Harris, L.B. and Lungan, A. (1988) Structural Control of Greenstone-Hosted Gold Mineralization by Transcurrent Shearing: A New Interepretation of the Kalgoorlie Mining District, Western Australia. Ore Geology Review, 3, 359-387. https://www.sciencedirect.com/science/article/pii/0169136888900273 https://doi.org/10.1016/0169-1368(88)90027-3

[5] Meert, J., Pandit, M.K., Pradhan, V.R., Banks, J., Sirianni, R., Stroud, M., Newstead, B. and Gifford J. (2010) Precambrian Crustal Evolution of Peninsular India: A 3.0 Billion Year Odyssey. Journal of Asian Earth Sciences, 39, 483-515. https://doi.org/10.1016/j.jseaes.2010.04.026

[6] Swami Nath, J. and Ramakrishnan, M. (1981) The Early Precambrian Supracrustals of Southern Karnataka. Memoirs of the Geological Survey of India, 112, 350. https://searchworks.stanford.edu/view/4522181

[7] Chadwick, B., Vasudev, V.N. and Hegde, G.V. (2000) The Dharwar Craton, Southern India, Interpreted as the Result of Late Archaean Oblique Convergence. Precambrian Research, 99, 91-101.

https://www.researchgate.net/publication/222991666 https://doi.org/10.1016/S0301-9268(99)00055-8

[8] Chadwick, B., Vasudev, V., Hegde, G.V. and Nutman, A.P. (2007) Structure and SHRIMP U/Pb Zircon Ages of Granites Adjacent to the Chitradurga Schist Belt: Implications for Neoarchean Convergence in the Dharwar Craton, Southern India. Journal of the Geological Society of India, 69, 5-24. https://books.google.co.in/books?id=bDmsBwAAQBAJ\&pg=PA48\&lpg=PA48\&dq

[9] Chardon, D., Peucat, J.J., Jayananda, M., Choukroune, P. and Fanning, C.M. (2002) Archean Granite-Greenstone Tectonics at Kolar (South India): Interplay of Diapirism and Bulk in Homogenous Shortening during Juvenile Magmatic Accretion. Tectonics, 21, 1-7. https://doi.org/10.1029/2001TC901032

[10] Ram Mohan, M., Piercey, S.J., Kamber, B.S. and Sarma, S. (2013) Subduction Related Tectonic Evolution of the Neoarchean Eastern Dharwar Craton, Southern India: New Geochemical and Isotopic Constraints. Precambrian Research, 227, 204-226. https://www.esd.mun.ca/ spiercey/Piercey_Research_Site/Publications_files/Moha n_in_press.pdf https://doi.org/10.1016/j.precamres.2012.06.012

[11] Krogstad, E.J., Balakrishnan, S., Hanson, G.N. and Rajamani, V. (1989) Plate Tec- 
tonics at $2.5 \mathrm{Ga}$ Ago: Evidence from Kolar Schist Belt, South India. Science, 243, 1337-1340. https://www.jstor.org/stable/1703681?seq=1\#page_scan_tab_contents https://doi.org/10.1126/science.243.4896.1337

[12] Anand, R. and Balakrishnan, S. (2010) Pb, Sr and Nd Isotope Systematics of Metavolcanic Rocks of the Hutti Greenstone Belt, Eastern Dharwar Craton: Constraints on Age, Duration of Volcanism and Evolution of Mantle Sources during Late Archean. Journal of Asian Earth Sciences, 39, 1-11.

http://www.sciencedirect.com/science/article/pii/S1367912010000647 https://doi.org/10.1016/j.jseaes.2010.02.010

[13] Anand, R., Balakrishnan, S., Kooijman, E. and Mezger, K. (2014) Neoarchean Crustal Growth by Accretionary Processes: Evidence from Combined Zircon-Titanite $\mathrm{U}-\mathrm{Pb}$ Isotope Studies on Granitoid Rocks around the Hutti Greenstone Belt, Eastern Dharwar Craton, India. Journal of Asian Earth Sciences, 79, 72-85.

https://docslide.com.br/documents/neoarchean-crustal-growth-by-accretionary-pro cesses-evidence-from-combined.html https://doi.org/10.1016/j.jseaes.2013.09.017

[14] Phani, R. (2014) Mineral Resources of Telangana State, India: The Way Forward. International Journal of Innovative Research in Science, Engineering and Technology, 3, 15450-15459.

https://www.ijirset.com/upload/2014/august/52_Mineral.pdf

[15] Jayananda, M., Peucat, J.J., Chardon, D., Krishna, R.B., Fanning, C.M. and Corfu, F. (2013) Neoarchean Greenstone Volcanism and Continental Growth, Dharwar Craton, Southern India: Constraints from SIMS U-Pb Zircon Geochronology and $\mathrm{Nd}$ Isotopes. Precambrian Research, 227, 55-76. http://repository.ias.ac.in/102872/

[16] Balakrishnan, S., Rajamani, V. and Hanson, G. (1999) U-Pb Ages for Zircon and Titanite from Ramagiri Area, Southern India: Evidence for Accretionary Origin of the Eastern Dharwar Craton during the Late Archaean. The Journal of Geology, 107 69-86. https://doi.org/10.1086/314331 https://books.google.co.in/books?id=BWhQpIteGE0C\&pg=PA102\&lpg=PA102\&dq =Balakrishnan, + S., + Rajamani, + V., + and + Hanson, + G.+(1999)

[17] Rajamanikam, M., et al. (2014) Rb-Sr and Sm-Nd Isotope Systematics and Geochemical Studies on Metavolcanic Rocks from Peddavura Greenstone Belt: Evidence for Presence of Mesoarchean Continental Crust in Easternmost Part of Dharwar Craton, India. Journal of Earth System Science, 123, 989-1011. http://www.ias.ac.in/article/fulltext/jess/123/05/0989-1011

[18] Geology of Andhra Pradesh Book from Geological Survey of India, Introduction about Peddavura Schist Belt. 53-55. 